\title{
Identification and Synthesis of a Female-Produced Sex Pheromone for the Cerambycid Beetle Prionus californicus
}

\author{
Joshua Rodstein • J. Steven McElfresh • \\ James D. Barbour • Ann M. Ray • \\ Lawrence M. Hanks • Jocelyn G. Millar
}

Received: 15 December 2008 / Revised: 20 March 2009 /Accepted: 27 March 2009/Published online: 25 April 2009

(C) The Author(s) 2009. This article is published with open access at Springerlink.com

\begin{abstract}
Females of the large cerambycid beetle Prionus californicus produce a powerful sex pheromone that attracts males. The pheromone was adsorbed on solid phase microextraction (SPME) fibers inserted into the ovipositor sheath and analyzed by coupled gas chromatographyelectroantennogram detection and GC-mass spectrometry. The pheromone was identified as an isomer of 3,5dimethyldodecanoic acid by a combination of retention index comparisons and mass spectral interpretation. The mass spectrum was misleading because it exhibited enlarged fragment ions that were not representative of branch points or other obvious stabilizing structural elements. The structure was verified by synthesis of 3,5-dimethyldodecanoic acid as a mixture of all four possible isomers, and this mixture was highly attractive to male beetles in field bioassays. The SPME
\end{abstract}

Electronic supplementary material The online version of this article (doi:10.1007/s10886-009-9623-7) contains supplementary material, which is available to authorized users.

J. Rodstein · J. G. Millar

Department of Chemistry, University of California,

Riverside, CA 92521, USA

J. S. McElfresh • J. G. Millar $(\bowtie)$

Department of Entomology, University of California,

Riverside, CA 92521, USA

e-mail: Jocelyn.millar@ucr.edu

J. D. Barbour

Southwest Idaho Research and Extension Center,

University of Idaho,

Parma, ID 83660, USA

A. M. Ray $\cdot$ L. M. Hanks

Department of Entomology,

University of Illinois at Urbana-Champaign,

Urbana, IL 61801, USA extracts also contained several other compounds that were tentatively identified as chain-extended homologs of the main pheromone component. This pheromone should prove useful for sampling and management of the beetle, which is an important pest of hops, and an occasional pest in a variety of orchard crops. Although this is the first female-produced pheromone to be identified from the Cerambycidae, there is considerable evidence for pheromone production by females of other species in the subfamily Prioninae. Thus, this pheromone and the associated methodology used in its identification should be useful in the identification of female-produced attractant pheromones from other members of the subfamily.

Keywords 3,5-dimethyldodecanoic acid .

3,5-dimethyltridecanoic acid · 3,5-dimethylpentadecanoic acid $\cdot$ Cerambycidae $\cdot$ Prioninae $\cdot$ Coleoptera

\section{Introduction}

Prionus californicus Motschulsky (Coleoptera: Cerambycidae), commonly known as the California prionus, ranges throughout much of western North America, being found from Alaska south to Mexico and as far east as the Rocky Mountains and Colorado (Linsley 1962). The adults are among the largest longhorned beetles in North America (Linsley 1962). The beetle has a long life cycle (3-5 years or more), spending most of its life underground as a rootfeeding larva. The fully developed larvae pupate in spring, and the adults appear in a relatively synchronized emergence from early- to mid-summer. The nonfeeding adult life stage is relatively short (a few weeks at most), and the adults must find mates and reproduce quickly before they exhaust their energy reserves and die (JDB, pers. obs.). 
Prionus californicus has a broad host range, feeding on the roots of a wide variety of perennials, and is an occasional to chronic pest of oaks, apple, cherry, almond, and many other species of woody plants in natural, agricultural, and urban environments (Solomon 1984). It is a particularly serious pest in the production of hop, Humulus lupulus L. (Urticales: Cannabaceae), in the northwestern USA (Bishop et al. 1984). Infestations in crops are difficult to manage because the developing larvae are protected within the roots of the host crop. Furthermore, insecticides may be ineffective against the adults because they do not feed and have a heavily sclerotized cuticle. We initiated a project to identify the sex pheromone of $P$. californicus as a first step in the possible development of noninsecticidal methods of monitoring and managing this important pest.

In preliminary studies, we showed that female $P$. californicus produce a powerful sex pheromone that specifically attracts males (Cervantes et al. 2006). The pheromone appeared to be produced by structures associated with the ovipositor, and "calling" females exhibited a stereotypical behavior of rhythmic extension and contraction of the ovipositor, with the eversion of a small sac-like projection from the dorsal surface of the ovipositor (Barbour et al. 2006). Here, we report the identification, synthesis, and preliminary field testing of a sex pheromone of $P$. californicus. This is the first female-produced sex attractant pheromone to be identified from this large beetle family, with more than 30,000 described species (Lawrence 1982).

\section{Methods and Materials}

Insects Insects were reared individually with pieces of hop root in 19-1 buckets buried in the ground at the Southwest Idaho Research and Extension Center, as previously described (Cervantes et al. 2006). Each bucket was covered with a screened lid, and adult beetles were collected as they emerged. Adult beetles were shipped within $24 \mathrm{~h}$ after emergence by overnight courier to UC Riverside (USDA-APHIS permit 71758), where they were held at $\sim 4^{\circ} \mathrm{C}$ in individual vials with a piece of moistened paper towel until used in experiments. Insects were used within 7 days after arrival at UC Riverside and, therefore, were 2-9 days old when used in experiments. Female $P$. californicus are receptive to mating within $24 \mathrm{~h}$ after emergence (Barbour et al. 2007).

Collection and Analysis of Pheromone Dissection and examination revealed that the eversible sac-like projection of females was contained in the ovipositor sheath, so we sampled directly from this structure. Thus, a live virgin female was held firmly while the ovipositor was gently pulled out to its full extension and clamped with a hemostat. The tip of a solid phase microextraction device fiber (polydimethylsiloxane coated fiber, $100-\mu \mathrm{m}$ thick film, Supelco, Inc., Bellefonte PA, USA) was then inserted into the opening from which the sac-like structure was everted and moved around to adsorb constituents by contact for $\sim 1 \mathrm{~min}$. One SPME fiber was used to sequentially sample from as many as 17 females to provide sufficient adsorbed material for analysis. SPME fibers were cleaned immediately before use by thermal desorbtion at $250^{\circ} \mathrm{C}$ for $10 \mathrm{~min}$ in the injector port of a gas chromatograph. Synthetic standards (see below) were adsorbed on SPME fibers by exposing the fibers to the headspace odors from a filter paper treated with a test compound and held in a vial sealed with aluminum foil.

The loaded SPME fibers were wiped gently with a paper tissue to remove any adhering materials before analysis. Loaded fibers initially were analyzed by coupled gas chromatography-electroantennogram detection (GC-EAD), using two Hewlett-Packard 5890 series II gas chromatographs (HP, Avondale PA, USA). The first GC was fitted with a DB-5 column $(30 \mathrm{~m} \times 0.25 \mathrm{~mm} \mathrm{ID}, 0.25 \mu \mathrm{m}$ film, programmed from $100^{\circ} \mathrm{C} / 1 \mathrm{~min}, 10^{\circ} / \mathrm{min}$ to $275^{\circ} \mathrm{C}$ for $15 \mathrm{~min}$; J\&W Scientific, Folsom, CA, USA), and the second with a DB-WAX column $(30 \mathrm{~m} \times 0.25 \mathrm{~mm} \mathrm{ID}$, $0.25 \mu \mathrm{m}$ film, $100^{\circ} \mathrm{C} / 1 \mathrm{~min}, 10^{\circ} / \mathrm{min}$ to $\left.240^{\circ}\right)$. Loaded SPME fibers were desorbed in the injection port for $1 \mathrm{~min}$ prior to starting the temperature program. Helium was used as the carrier and makeup gas, and all injections were made in splitless mode. The column effluent was split equally with a glass X-shaped union (Restek, Bellefonte PA, USA) fitted with $0.32 \mathrm{~mm}$ ID sections of uncoated and deactivated GC column, with one section going to the flame ionization detector (FID), another to the electroantennogram detector (EAD), and the final section providing helium makeup gas ( $3 \mathrm{ml} / \mathrm{min}$ ). The EAD branch passed through a heated conduit $\left(250^{\circ} \mathrm{C}\right)$ and into the side of a $15 \mathrm{~mm}$ ID glass tube swept with humidified medical air $(770 \mathrm{ml} / \mathrm{min})$, with the air flow directed over the insect antennal preparation. Signals were recorded on either matched HP 3394 integrators or with an SRI model 202 PeakSimple chromatography data system running on a personal computer with PeakSimple v. 2.83 software (SRI Instruments, Torrance, CA, USA).

Males used in GC-EAD analyses were not chilled or anesthetized prior to use. The five terminal flagellomeres (out of total number of 12) of one antenna were cut off, and $\sim 1 \mathrm{~mm}$ of the tip was removed with a razor blade. The section of antenna then was mounted between two glass capillary electrodes filled with Locke's saline (7.5 g NaCl, $0.21 \mathrm{~g} \mathrm{CaCl}_{2}, 0.35 \mathrm{~g} \mathrm{KCl} 0.2 \mathrm{~g} \mathrm{NaHCO}_{3}$ per liter distilled water), with electrical contact to the amplifier being provided with $0.2-\mathrm{mm}$ gold wires. The antennal preparation was centered in the effluent air stream from the GC, and antennal signals were amplified and filtered with a custombuilt amplifier and recorded in parallel with the FID signals, as described above. 
Loaded SPME fibers also were analyzed by GC-MS, using an HP $6890 \mathrm{GC}$ interfaced to an HP 5973 mass selective detector (MSD), or an Agilent $6890 \mathrm{~N} \mathrm{GC}$ interfaced to a 5975C MSD, both fitted with HP5-MS columns (30 $\mathrm{m} \times$ $0.25 \mathrm{~mm} \mathrm{ID}$, temperature program $40^{\circ} \mathrm{C} / 0 \mathrm{~min}, 10^{\circ} \mathrm{C} / \mathrm{min}$ to $280^{\circ} \mathrm{C}$, hold $15 \mathrm{~min}$ ). SPME fibers were desorbed for $30 \mathrm{~s}$ in splitless mode before beginning temperature programming. Kovats indices (Kovats 1965) of analytes were calculated with reference to straight-chain hydrocarbons.

Synthesis of the Pheromone and Analogs Tetrahydrofuran (THF) was distilled from sodium/benzophenone ketyl under argon. ${ }^{1} \mathrm{H}$ - and ${ }^{13} \mathrm{C}$-NMR spectra were recorded with a Varian INOVA-400 (400 and $100.5 \mathrm{MHz}$, respectively) spectrometer, as $\mathrm{CDCl}_{3}$ solutions. Chemical shifts are expressed in ppm relative to $\mathrm{CDCl}_{3}$ ( 7.27 and $77.23 \mathrm{ppm}$ for ${ }^{1} \mathrm{H}$ and ${ }^{13} \mathrm{C}$ NMR, respectively). Worked-up solutions were dried over anhydrous $\mathrm{Na}_{2} \mathrm{SO}_{4}$, and concentrated by rotary evaporation under reduced pressure. Crude products were purified by flash or vacuum flash chromatography on silica gel (230-400 mesh). Mass spectra of synthetic intermediates were obtained with a Hewlett-Packard 5890 GC interfaced to an HP 5970 mass selective detector, in EI mode $(70 \mathrm{eV})$ with helium carrier gas. The $\mathrm{GC}$ was equipped with an HP5-MS column $(25 \mathrm{~m} \times 0.20 \mathrm{~mm}$ ID $\times 0.33-\mu \mathrm{m}$ film). Reactions with air- or water-sensitive reagents were carried out in dried glassware under argon atmosphere.

Syntheses of Trimethylundecanoic and 3,5-Dimethyldodecanoic Acids: Synthesis of 3,5,9-Trimethylundecanoic Acid

4,6-Dimethyl-2-Oxepanone (2) A solution of 3,5-dimethylcyclohexanone 1 (6.341 g, $50 \mathrm{mmol}), m$-chloroperbenzoic acid (approximately $\sim 67 \%$ by weight, $12.93 \mathrm{~g}, \sim 50 \mathrm{mmol}$ ), and trifluoroacetic acid $(0.384 \mathrm{~g}, 5 \mathrm{mmol})$ in methylene chloride $(140 \mathrm{ml})$ was stirred in an ice bath for $1 \mathrm{~h}$, then warmed to room temperature and stirred until the reaction was complete $(\sim 24 \mathrm{~h})$. The mixture was then held at $\sim 4^{\circ} \mathrm{C}$ overnight to precipitate most of the $m$-chlorobenzoic acid and then filtered with suction, rinsing with hexanes. The filtrate was stirred with dilute sodium bisulfite solution $(75 \mathrm{ml})$ for $4 \mathrm{~h}$ to destroy any remaining $m$-chloroperbenzoic acid. After separation of the layers, the organic layer was washed twice with saturated sodium bicarbonate solution and brine then dried and concentrated, yielding $6.11 \mathrm{~g}(86 \%)$ of 4,6-dimethyl-2-oxepanone $2,96 \%$ pure by GC. This was used in the next step without further purification. ${ }^{1} \mathrm{H}$ NMR $\left(400 \mathrm{MHz}, \mathrm{CDCl}_{3}\right): \delta 0.92(\mathrm{~d}, J=$ $6.9 \mathrm{~Hz}, 3 \mathrm{H}), 0.98-1.10(\mathrm{~m}, 1 \mathrm{H}), 1.04(\mathrm{~d}, J=6.6 \mathrm{~Hz}, 3 \mathrm{H})$, 1.25 (t, $J=6 \mathrm{~Hz}, 1 \mathrm{H}), 2.0(\mathrm{~m}, 3 \mathrm{H}), 2.49(\mathrm{~m}, 2 \mathrm{H}), 4.05(\mathrm{~m}$, 2H). $\left.{ }^{13} \mathrm{C} \mathrm{NMR} \mathrm{(100} \mathrm{MHz,} \mathrm{CDCl}_{3}\right): \delta 19.1,24.3,30.0,34.2$, 42.3, 47.0, 74.4, 175.1. MS: $m / z$ (\%): 170 (2), 142 (3), 112 (55), 97 (29), 83 (9), 69 (100), 56 (45), 55 (55), 43 (28), 42 (75), 41 (89; Scheme 1).

Methyl 6-Hydroxy-3,5-Dimethylhexanoate (3) Sodium metal $(0.210 \mathrm{~g}, 9 \mathrm{mmol})$ was added to dry $\mathrm{MeOH}(40 \mathrm{ml})$ in a dry three-neck flask under argon at $0^{\circ} \mathrm{C}$, and the mixture was stirred until the Na had completely dissolved. 4,6-Dimethyl2-oxepanone 2 (6.11 g, $43 \mathrm{mmol}$ ) was added dropwise, and the reaction was stirred at room temperature for $2.5 \mathrm{~h}$, then quenched with $1 \mathrm{M} \mathrm{HCl}(100 \mathrm{ml})$ and extracted three times with ether. The combined ether extracts were washed sequentially with water, saturated aqueous sodium bicarbonate, and brine, then dried and concentrated. The crude methyl 6-hydroxy-3,5-dimethylhexanoate $3(5.47 \mathrm{~g}, 87 \%$ pure by GC, $73 \%$ crude yield) was used in the next step
Scheme 1 Synthesis of 3,5,9trimethylundecanoic acid. a $m$-chloroperbenzoic acid, TFA, $\mathrm{CH}_{2} \mathrm{Cl}_{2} ; b \mathrm{NaOMe}$, $\mathrm{MeOH} ; c$ TosCl, pyridine, DMAP; $d \mathrm{PBr}_{3}$, ether; $e \mathrm{Mg}$ turnings, THF; $f \mathrm{Li}_{2} \mathrm{CuCl}_{4}$, tosylate 4, THF; $g \mathrm{KOH}$, $\mathrm{MeOH} / \mathrm{H}_{2} \mathrm{O}$
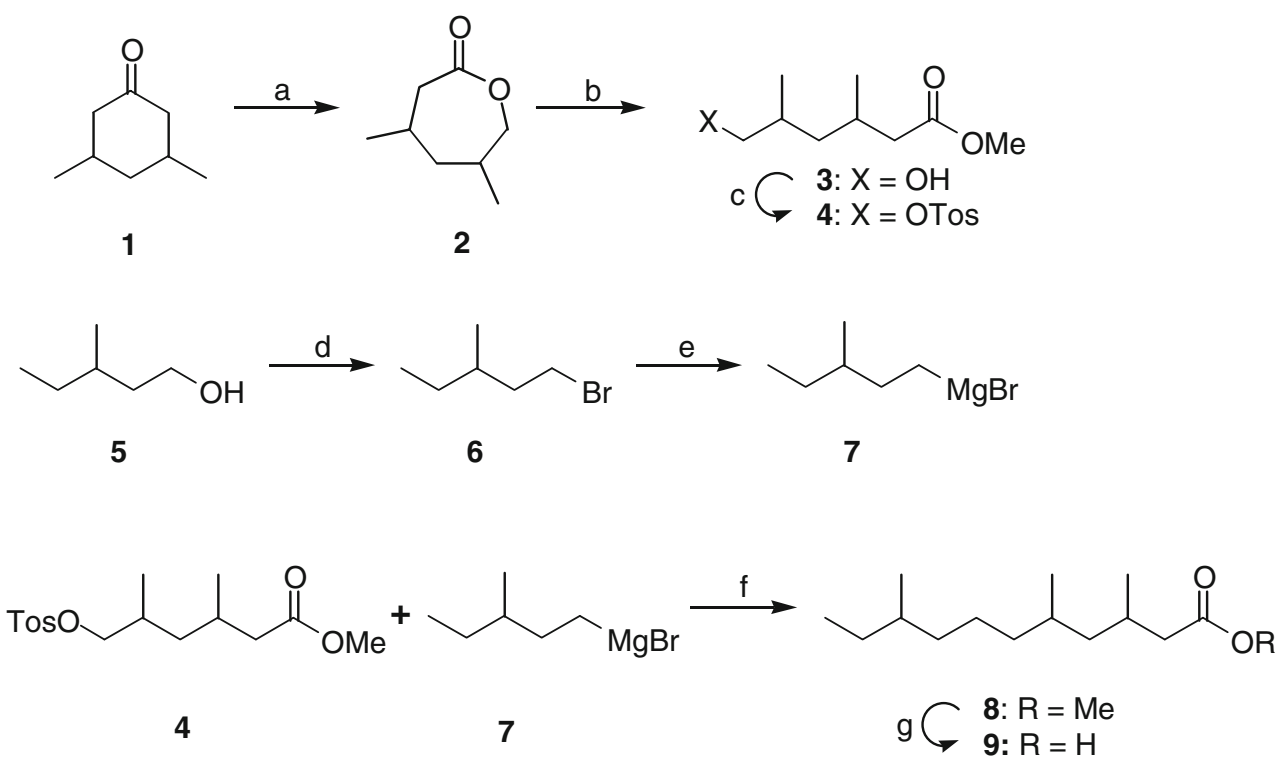
without further purification. ${ }^{1} \mathrm{H} \mathrm{NMR}\left(400 \mathrm{MHz}, \mathrm{CDCl}_{3}\right): \delta$ 0.92 (d, $J=6.8 \mathrm{~Hz}, 3 \mathrm{H}), 0.95$ (d, $J=6.5 \mathrm{~Hz}, 3 \mathrm{H}), 1.01$ (m, 2H), 1.32-1.42 (m, 1H), 1.63-1.73 (m, 1H), 1.75 (br. s, 1H), 2.0-2.08 (m, 1H), $2.11(\mathrm{dd}, J=14.9,7.5,1 \mathrm{H}), 2.30$ (dd, $J=14.9,6.0,1 \mathrm{H}), 3.48$ (d, $J=5.6 \mathrm{~Hz}, 2 \mathrm{H}), 3.66(\mathrm{~s}, 3 \mathrm{H})$. ${ }^{13} \mathrm{C}$ NMR (100 MHz, $\left.\mathrm{CDCl}_{3}\right): \delta 17.6,20.7,27.8,33.2,40.7$, 41.4, 51.7, 67.9, 174.1. MS m/z (\%): 161 (5), 115 (6), 101 (9), 97 (5), 83 (17), 74 (100), 69 (12), 59 (22), 55 (30), 43 (29), 42 (13), 41 (39).

Methyl 6-[[(4-methylphenyl)sulfonyl]oxy]-3,5 dimethylhexanoate (4) p-Toluenesulphonyl chloride (10.3 g, $53 \mathrm{mmol})$ was added to a solution of 6-hydroxy-3,5-dimethylhexanoate 3 (5.47 g, $31 \mathrm{mmol})$ and dimethylaminopyridine $(0.425 \mathrm{~g}$, $3.4 \mathrm{mmol}$ ) in $40 \mathrm{ml}$ pyridine at room temperature, and the mixture was stirred $12 \mathrm{~h}$. The mixture was then poured into excess $1 \mathrm{M} \mathrm{HCl}$ and extracted with ether. The ether layer was washed with saturated aqueous sodium bicarbonate and brine. The sodium bicarbonate and brine layers were back extracted with ether, and the combined organic layers were dried and concentrated. The crude residue was purified by vacuum flash chromatography (95:5 hexanes:EtOAc, then $100 \%$ EtOAc) to yield $6.01 \mathrm{~g}(58.2 \%)$ of tosylate 4 of $74 \%$ purity by gas chromatography, along with $13 \%$ of recovered 4,6-dimethyl-2-oxepanone 2. A smaller sample was repurified to obtain spectral data, yielding tosylate 4 as a 93:7 mixture of diastereomers (total, 96\% chemically pure by GC). ${ }^{1} \mathrm{H} \mathrm{NMR}\left(400 \mathrm{MHz}, \mathrm{CDCl}_{3}\right): \delta 0.91(\mathrm{~d}, J \sim 5.6 \mathrm{~Hz}$, $3 \mathrm{H}), 0.92$ (d, J 6.8 Hz, 3H), 0.85-1.04 (m, 1H), 1.31 (m, 1H), 1.80-2.02 (m, 2H), 2.04 (dd, $J=14.7,8.3 \mathrm{~Hz}, 1 \mathrm{H})$, $2.23(\mathrm{dd}, J=14.7,5.2 \mathrm{~Hz}, 1 \mathrm{H}), 2.46$ (s, 3H), 3.67 (s, 3H), 3.79 (dd, $J=9.5,6.5 \mathrm{~Hz}, 1 \mathrm{H}), 3.90$ (dd, $J=9.5,5.3 \mathrm{~Hz}, 1 \mathrm{H})$, $7.36(\mathrm{~d}, J=8.3 \mathrm{~Hz}, 2 \mathrm{H}), 7.80$ (d, $J=8.3 \mathrm{~Hz}, 2 \mathrm{H}) .{ }^{13} \mathrm{C} \mathrm{NMR}$ $\left(100 \mathrm{MHz}, \mathrm{CDCl}_{3}\right): \delta 17.3,20.5,21.8,27.8,30.6,37.8$, 37.8, 40.2, 41.3, 51.7, 75.0, 128.1, 130.0, 133.3, 144.9, 173.4. MS: $m / z$ (\%): 328 (3), 297 (8), 254 (1), 232 (9), 173 (9), 155 (35), 141 (26), 125 (13), 114 (17), 111 (12), 101 (16), 96 (25), 91 (80), 83 (100), 74 (19), 69 (38), 55 (60), 41 (55).

1-Bromo-3-methylpentane (6) $\mathrm{PBr}_{3}$ (4.84 g, $17.8 \mathrm{mmol}$ ) was added dropwise to a solution of 3-methylpentanol 5 $(5.02 \mathrm{~g}, 48.8 \mathrm{mmol})$ in dry ether $(65 \mathrm{ml})$ at $0^{\circ} \mathrm{C}$, shielding the reaction from light. The reaction was allowed to warm to room temperature and stirred overnight. The reaction was then poured into ice water and extracted with ether. The ether layer was washed sequentially with saturated aqueous sodium bicarbonate and brine, then dried and concentrated by fractional distillation of the ether with a short Vigreux column. The resulting oil was Kugelrohr distilled (oven temp. $\sim 70^{\circ} \mathrm{C}, 3-4$ Torr) to yield $3.904 \mathrm{~g}(48.4 \%)$ of bromide 6 as a colorless oil. ${ }^{1} \mathrm{H}$ NMR (300 $\left.\mathrm{MHz}, \mathrm{CDCl}_{3}\right): \delta 0.90(\mathrm{t}$, $J=7.4 \mathrm{~Hz}, 3 \mathrm{H}), 0.90$ (d, $J=6.5 \mathrm{~Hz}, 3 \mathrm{H}), 1.18$ (m, 1H), 1.36 (m, 1H), 1.5-1.75 (m, 2H), $1.88(\mathrm{~m}, 1 \mathrm{H}), 3.43$ (m, 2H). MS $m / z$ (\%): 166 (2), 164 (2), 137 (1), 135 (2), 109 (3), 107 (5), 95 (2), 93 (2), 85 (53), 69 (25), 57 (90), 41 (100).

Methyl 3,5,9-trimethylundecanoate (8) Freshly ground magnesium turnings $(1.149 \mathrm{~g}, 46 \mathrm{mmol})$ were added to a dry three-neck flask under argon, and a $\sim 4-\mathrm{ml}$ aliquot of a solution of 1-bromo-3-methylpentane 6 (3.223 g, $23.6 \mathrm{mmol}$ ) in $20 \mathrm{ml}$ dry THF was added. The mixture was stirred until the Grignard reaction started, followed by addition of the remainder of the solution by syringe pump over $1 \mathrm{~h}$. After the addition was complete, the mixture was stirred for an additional $1 \mathrm{~h}$ then allowed to stand so that fine solids could settle out.

Dry THF $(16 \mathrm{ml})$, lithium tetrachlorocuprate solution (7 ml, $0.1 \mathrm{M}$ in THF, $0.7 \mathrm{mmol}$ ), and tosylate 4 (5.047 g, $15.3 \mathrm{mmol}$ ) were added to a dry three-neck flask under argon, and the mixture was chilled in an ice bath. The freshly prepared solution of 3-methylpentylmagnesium bromide 7 was added dropwise, maintaining the temperature at $\sim 0^{\circ} \mathrm{C}$. After the addition was complete, the reaction was stirred $1 \mathrm{~h}$ at $0^{\circ} \mathrm{C}$, and then allowed to warm slowly to room temperature overnight. The reaction was then quenched with $1 \mathrm{M} \mathrm{HCl}$, and the mixture was extracted with ether. The ether layer was washed sequentially with saturated aqueous sodium bicarbonate and brine, then dried and concentrated. The residue was purified by column chromatography (95:5 hexanes/ethyl acetate), yielding $0.45 \mathrm{~g}$ of the desired product $8(12.2 \%)$ and $3.36 \mathrm{~g}$ (10.2 mmol, 66\%) of unreacted tosylate 4. ${ }^{1} \mathrm{H}$ NMR $\left(400 \mathrm{MHz}, \mathrm{CDCl}_{3}\right): \delta 0.86(\mathrm{~m}, 9 \mathrm{H}), 0.93(\mathrm{~d}, J=6.2 \mathrm{~Hz}$, $3 \mathrm{H}), 0.95-1.17(\mathrm{~m}, 4 \mathrm{H}), 1.18-1.38(\mathrm{~m}, 7 \mathrm{H}), 1.46(\mathrm{~m}, 1 \mathrm{H})$, $2.05(\mathrm{~m}, 2 \mathrm{H}), 2.31(\mathrm{~m}, 1 \mathrm{H}), 3.67(\mathrm{~s}, 3 \mathrm{H}) .{ }^{13} \mathrm{C} \mathrm{NMR}$ $\left(100 \mathrm{MHz}, \mathrm{CDCl}_{3}\right): 11.59,19.37,19.45,20.24,20.29$, $20.58,24.44,28.08,29.63,29.78,30.22,30.26,34.60$, 37.05, 37.12, 37.21, 41.75, 44.85, 44.91, 51.52, 174.03. MS: $m / z(\%): 185$ (12), 143 (10), 131 (2), 115 (7), 101 (88), 83 (30), 74 (100), 59 (25), 55 (51), 41 (72).

3,5,9-Trimethylundecanoic Acid (9) A mixture of methanol (31 ml), water $(3.4 \mathrm{ml}), \mathrm{KOH}(0.94 \mathrm{~g}, 17 \mathrm{mmol})$, and methyl 3,5,9-trimethylundecanoate 8 (0.201 g, $0.82 \mathrm{mmol})$ was refluxed $1 \mathrm{~h}$, then cooled to room temperature. The mixture was acidified with $1 \mathrm{M} \mathrm{HCl}$, then extracted three times with ether. The combined ether layers were washed with brine, then dried and concentrated, to yield 3,5,9trimethylundecanoic acid $\mathbf{9}$ as a mixture of stereoisomers (0.169 g, 88.9\%). ${ }^{1} \mathrm{H}$ NMR (400 MHz, $\left.\mathrm{CDCl}_{3}\right): \delta 0.86(\mathrm{~m}$, $9 \mathrm{H}), 0.97$ (two overlapped $\mathrm{d}, 3 \mathrm{H}), 0.98-1.52(\mathrm{~m}, 10 \mathrm{H})$, $2.08(\mathrm{~m}, 2 \mathrm{H}), 2.36(\mathrm{~m}, 1 \mathrm{H}) .{ }^{13} \mathrm{C} \mathrm{NMR}\left(100 \mathrm{MHz}, \mathrm{CDCl}_{3}\right)$ : $\delta 11.60,19.38,20.22,20.5,24.42,27.91,29.64,29.78$, $34.60,37.12,41.50,44.75,44.82,179.01$. MS: $\mathrm{m} / z(\%)$ : 199 (5), 129 (100), 111 (33), 97 (22), 89 (22), 83 (10), 71 (87), 43 (37). 
Synthesis of 3,5,7-Trimethylundecanoic Acid (13)

Methyl 6-iodo-3,5-dimethylhexanoate (10) A solution of methyl 6-hydroxy-3,5-dimethylhexanoate 3 (2.3 g, $13.2 \mathrm{mmol})$ and triethylamine $(3.70 \mathrm{ml}, 26.4 \mathrm{mmol})$ in ether $(66 \mathrm{ml})$ was cooled to $-5^{\circ} \mathrm{C}$ in an ice-salt bath, and methanesulphonyl chloride $(1.24 \mathrm{ml}, 15.8 \mathrm{mmol})$ was added dropwise. The reaction was stirred for $30 \mathrm{~min}$, then quenched with dilute sodium bicarbonate. The organic layer was separated and washed sequentially with $1 \mathrm{M} \mathrm{HCl}$, water, and brine, then dried and concentrated. The crude mesylate was taken up in acetone $(66 \mathrm{ml})$, and $\mathrm{NaI}(6.92 \mathrm{~g}$, $46 \mathrm{mmol}$ ) was added. The mixture was stirred 8 days at room temperature then concentrated by rotary evaporation. The residue then was partitioned between water and ether. The ether layer was washed with brine, dried, and concentrated. The residue was purified by flash chromatography (hexane/EtOAc 95:5) yielding $3.07 \mathrm{~g}(81 \%)$ of iodide 10. ${ }^{1} \mathrm{H}$ NMR (400 MHz, CDCl3): $\delta 0.96(\mathrm{~d}, 2 \mathrm{H}$, $J=6.5 \mathrm{~Hz}), 0.99$ (d, 2H, $J=6.5 \mathrm{~Hz}), 1.1(\mathrm{~m}, 1 \mathrm{H}), 1.35(\mathrm{~m}$, $1 \mathrm{H}), 1.55(\mathrm{~m}, 1 \mathrm{H}), 2.04(\mathrm{~m}, 1 \mathrm{H}), 2.16(\mathrm{dd}, 1 \mathrm{H}, J=14.6$, $8.0 \mathrm{~Hz}), 2.30(\mathrm{dd}, 2 \mathrm{H}, J=14.6,5.6 \mathrm{~Hz}), 3.15(\mathrm{dd}, 1 \mathrm{H}$, $J=11.7,5.9 \mathrm{~Hz}), 3.25(\mathrm{dd}, 1 \mathrm{H}, J=11.7,4.2 \mathrm{~Hz}), 3.68$ (s, 3H). $\left.{ }^{13} \mathrm{C} \mathrm{NMR} \mathrm{(100} \mathrm{MHz,} \mathrm{CDCl}_{3}\right): \delta 17.6,20.2,21.4$, 28.0, 32.1, 41.7, 43.7, 51.7, 173.5. MS $m / z$ (\%): 284 (trace), 253 (6), 235 (2), 183 (2), 157 (40), 141 (3), 125 (32), 97 (36), 83 (100), 73 (17), 69 (21), 55 (92), 41 (87).

3,5,7-Trimethylundecanoic acid (13) A dry three-neck flask was loaded with freshly ground magnesium turnings (0.86 g, $35.2 \mathrm{mmol})$ and THF $(17 \mathrm{ml})$ under argon. 2Bromohexane (2.80 g, $17 \mathrm{mmol}$; Alfa Aesar) was purified immediately before use by vacuum flash chromatography on silica gel, eluting with pentane. After concentration, the bromide was added dropwise over $1 \mathrm{~h}$ to the slurry of $\mathrm{Mg}$ turnings, and the mixture was stirred a further $3 \mathrm{~h}$ after the addition was complete. The resulting 2-hexylmagnesium bromide solution $\mathbf{1 1}$ was then added dropwise to an icebath-cooled solution of lithium tetrachlorocuprate $(1.8 \mathrm{ml}$, $0.18 \mathrm{mmol})$, THF (5 ml), and methyl 6-iodo-3,5-dimethylhexanoate $10(1.0 \mathrm{~g}, 3.51 \mathrm{mmol})$. The reaction was held at $\sim 0^{\circ} \mathrm{C}$ for $2 \mathrm{~h}$ then allowed to warm slowly to room temperature overnight. The mixture was quenched with $1 \mathrm{M} \mathrm{HCl}$ and extracted with ether. The ether layer was washed sequentially with saturated sodium bicarbonate and brine, dried, and concentrated. The resulting crude methyl 3,5,7-trimethylundecanoate $\mathbf{1 2}$ was refluxed $1 \mathrm{~h}$ in a mixture of methanol $(100 \mathrm{ml})$, water $(10 \mathrm{ml})$, and $\mathrm{KOH}$ (4.02 g, $71.6 \mathrm{mmol})$. After cooling, the mixture was diluted with water and any unreacted methyl ester and Wurtz coupling dimerization products from the Grignard reagent were removed by extracting the mixture twice with ether. The remaining aqueous layer was then acidified with $\mathrm{HCl}$ and extracted three times with ether. The combined ether extracts were washed with brine, dried, and concentrated, yielding $240 \mathrm{mg}$ of crude acid 13. ${ }^{1} \mathrm{H}$ NMR $(400 \mathrm{MHz}$, $\left.\mathrm{CDCl}_{3}\right): \delta 0.78-0.92(\mathrm{~m}, 9 \mathrm{H}), 0.93-0.99(\mathrm{~m}, 3 \mathrm{H}), 0.99$ $1.14(\mathrm{~m}, \sim 4 \mathrm{H}), 1.14-1.37(\mathrm{~m}, \sim 7 \mathrm{H}), 1.37-1.51(\mathrm{~m}, 1 \mathrm{H})$, $1.51-1.62(\mathrm{~m}, 1 \mathrm{H}), 2.07(\mathrm{~m}, 2 \mathrm{H}), 2.37(\mathrm{~m}, 1 \mathrm{H}) .{ }^{13} \mathrm{C} \mathrm{NMR}$ $\left(100 \mathrm{MHz}, \mathrm{CDCl}_{3}\right) \delta 14.40,19.57,20.14,20.31,20.54$, $20.59,20.73,20.78,23.23,23.74,27.52,27.62,27.77$, $27.87,29.33,29.54,30.06,30.15,36.41,37.99,38.01$, $41.34,41.69,44.48,44.88,45.25,45.60,179.40$. MS $m / z$ (\%): 228 (1), 210 (1), 192 (5), 171 (7), 169 (7), 153 (12), 143 (6), 139 (4), 129 (33), 111 (32), 101 (23), 87 (100), 69 (49), 57 (45), 43 (62).

Synthesis of 3,5-Dimethyldodecanoic Acid (18)

1-Bromo-2-methylnonane (15) Mesyl choride $(9.58 \mathrm{ml}$, $123 \mathrm{mmol})$ was added dropwise to a chilled solution $\left(\sim 10^{\circ} \mathrm{C}\right.$ in an ice-salt bath) of 2-methylnonanol 14 $(18.72 \mathrm{~g}, 112 \mathrm{mmol})$ in methylene chloride $(280 \mathrm{ml})$ and triethylamine $(23.2 \mathrm{ml}, 168 \mathrm{mmol})$. The resulting mixture was stirred $1 \mathrm{~h}$ at $\sim-10^{\circ} \mathrm{C}$ then filtered with suction. The filtrate was washed sequentially with $1 \mathrm{M} \mathrm{HCl}$, saturated $\mathrm{NaHCO}_{3}$, and brine, then dried and concentrated. The crude mesylate was taken up in acetone $(280 \mathrm{ml})$, and $\mathrm{LiBr}$ $(29.11 \mathrm{~g}, 336 \mathrm{mmol})$ was added in three portions (exothermic!), allowing the mixture to cool between additions of each portion. The mixture was stirred $3 \mathrm{~h}$ at room temperature then heated to $60^{\circ} \mathrm{C}$ overnight. After cooling to room temperature, the mixture was filtered with suction, and the filtrate was concentrated. The crude reaction mixture was diluted with pentane and washed with water and brine. After concentration, the residue was purified by vacuum flash chromatography on silica gel, eluting with pentane. The purified 1-bromo-2-methylnonane 15 then was Kugelrohr distilled (oven temp $\sim 65^{\circ} \mathrm{C}$ : 1.6 Torr), yielding $21.68 \mathrm{~g}$ of colorless oil (85\%), $91 \%$ pure by GC. ${ }^{1} \mathrm{H}$ NMR $\left(400 \mathrm{MHz}, \mathrm{CDCl}_{3}\right): \delta 0.89$ (t, $\left.J=6.78 \mathrm{~Hz}, 3 \mathrm{H}\right), 1.01$ $(\mathrm{d}, J=6.62 \mathrm{~Hz}, 3 \mathrm{H}), 1.28(\mathrm{~m}, 10 \mathrm{H}), 1.45(\mathrm{~m}, 1 \mathrm{H}), 1.80(\mathrm{~m}$, $1 \mathrm{H}), 3.33(\mathrm{dd}, 1 \mathrm{H}, J=9.75,6.24 \mathrm{~Hz}), 3.40(\mathrm{dd}, 1 \mathrm{H}, \mathrm{J}=9.75$, $4.94 \mathrm{~Hz}) .{ }^{13} \mathrm{C}$ NMR $\left(100 \mathrm{MHz}, \mathrm{CDCl}_{3}\right): \delta 14.29,18.99$, $22.85,27.08,29.44,29.86,32.04,35.07,35.41,41.83$. MS m/z (\%): 113 (trace), 98 (16), 85 (17), 71 (31), 57 (86), 41 $(100)$.

3,5-Dimethyldodecanoic Acid (18) 1-Bromo-2-methylnonane 15 (11.57 g, $52.3 \mathrm{mmol})$ was added dropwise to a slurry of Mg turnings (3.64 g, $150 \mathrm{mmol})$ in dry THF $(96 \mathrm{ml})$ under argon over $\sim 2 \mathrm{~h}$. The resulting solution of Grignard reagent 16 was then added by syringe to a slurry of $\mathrm{CuI}(0.678 \mathrm{~g}$, $3.56 \mathrm{mmol})$ and dry THF $(10 \mathrm{ml})$ in a dry three-neck flask cooled to $0^{\circ} \mathrm{C}$ under argon. Then, $\beta$-butyrolactone 17 $(5.38 \mathrm{~g}, 62.5 \mathrm{mmol})$ in dry THF $(44.6 \mathrm{ml})$ was added 
dropwise over $60 \mathrm{~min}$. The mixture was stirred at $0^{\circ} \mathrm{C}$ for $30 \mathrm{~min}$ and then warmed to room temperature overnight. The reaction was quenched with $1 \mathrm{M} \mathrm{HCl}$ and extracted with ether three times. The combined ether extracts were washed twice with $1 \mathrm{M} \mathrm{NaOH}$. The resulting combined aqueous layers then were acidified with $3 \mathrm{M} \mathrm{HCl}$, and extracted twice with ether. The combined ether layers were washed with brine, dried, and concentrated to give $6.7 \mathrm{~g}$ of crude acid 18 (47\%). Attempted Kugelrohr distillation of a portion of the crude acid resulted in decomposition, and so the remainder $(6.7 \mathrm{~g})$ was purified by flash chromatography (hexanes/EtOAc 3:1, with $1 \%$ acetic acid), giving $6.1 \mathrm{~g}$ of 3,5-dimethyldodecanoic acid $\mathbf{1 8}$ of $96 \%$ purity by GC. ${ }^{1} \mathrm{H}$ NMR $\left(400 \mathrm{MHz}, \mathrm{CDCl}_{3}\right): \delta 0.86(\mathrm{t}, 3 \mathrm{H}, J=6.6 \mathrm{~Hz})$, 0.88 and $0.90(\mathrm{dd}, 3 \mathrm{H}, J=6.7 \mathrm{~Hz}), 0.95$ and $0.97(\mathrm{dd}, 3 \mathrm{H}$, $J=6.4 \mathrm{~Hz}), 1.00-1.20(\mathrm{~m}, 2 \mathrm{H}), 1.27(\mathrm{~m}, 12 \mathrm{H}), 1.47(\mathrm{~m}, 1 \mathrm{H})$, $2.10(\mathrm{~m}, 1 \mathrm{H}), 2.3(\mathrm{~m}, 1 \mathrm{H}) .{ }^{13} \mathrm{C} \mathrm{NMR}\left(100 \mathrm{MHz}, \mathrm{CDCl}_{3}\right)$ : $\delta 14.3,19.5,19.6,20.2,20.5,22.9,27.0,27.2,27.9,27.9$, 29.6, 30.1, 30.2, 32.1, 36.8, 37.9, 41.5, 42.4, 44.5, 44.8, 179.1, 179.3 (MS: see Fig. 2C).

Field Bioassay of Synthetic Pheromone A field bioassay of the synthetic 3,5-dimethyldodecanoic acid was conducted at Placerita Canyon Natural Area (Los Angeles Co., CA), an area where adult $P$. californicus frequently are collected in light traps during summer months (I. P. Swift, pers. obs.). The bioassay was deployed from 12 to 17 June 2008 (clear skies, no precipitation, maximum air temperatures $21-36^{\circ} \mathrm{C}$ ). Traps consisted of $19-1$ polypropylene buckets $(38 \mathrm{~cm}$ tall $\times$ $30 \mathrm{~cm}$ diam) fitted with aluminum funnels (model 2815B, BioQuip, Rancho Dominguez, CA, USA) that were buried with the top of the funnel flush with the soil surface. Lures consisted of clear low density polyethylene press-seal bags (Bagette model 14770, 5.1 $\times 7.6 \mathrm{~cm}, 0.05 \mathrm{~mm}$ wall thickness, Cousin Corp., Largo, FL, USA) that were loaded with $100 \mathrm{mg}$ of synthetic 3,5-dimethyldodecanoic acid (as the mixture of four stereoisomers) in $900 \mu \mathrm{l}$ ethanol. Control lures consisted of bags loaded with $1 \mathrm{ml}$ of pure ethanol. Lures were hung inside trap funnels with wire. Traps were set up in a westerly transect in an area wooded with mature Quercus agrifolia Neé (position of first trap N 3422'42" W $118^{\circ} 28^{\prime} 53^{\prime \prime}, 462 \mathrm{~m}$ elevation). There were two sets of traps in the transect, each including two traps baited with pheromone and two control traps, with traps spaced $\sim 8 \mathrm{~m}$ apart, and with the sets separated by $60 \mathrm{~m}$. Traps were checked for beetles daily at 8:00 AM.

Differences between treatments in numbers of beetles captured were tested with the nonparametric Friedman's test (blocked by set and day, PROC FREQ with $\mathrm{CMH}$ option; SAS Institute 2001) because a mean of zero for controls violated assumptions of analysis of variance (Sokal and Rohlf 1995). We used a mark-recapture technique to estimate the local abundance of male P. californicus. All beetles that were removed from traps on 13-16 June 2008 were marked with a spot of blue fingernail polish on the pronotum and were released in wooded areas at least $20 \mathrm{~m}$ from traps. We recorded the number of marked individuals that were recaptured and used the Lincoln-Peterson index to estimate the size of the local population based on the accumulated number of marked beetles that had been released (Southwood and Henderson 2000).

Voucher specimens of $P$. californicus have been deposited at the Entomology Research Museum at the University of California, Riverside, CA.

\section{Results}

Identification of the Pheromone Gas chromatographyelectroantennogram detection analyses of the compounds collected from female beetles by contact SPME showed that the antennae of male $P$. californicus responded strongly to a compound present in nanogram quantities (estimated from peak size in GC-MS total ion current chromatograms) in the extracts (Fig. 1, peak 2), with additional responses to several other components (Fig. 1, peaks 1, 3, and 4). Analyses of SPME samples by GC-MS produced a mass spectrum (Fig. 2A) that suggested that the most active compound had a probable molecular weight of $228 \mathrm{Da}$, for a possible molecular formula of $\mathrm{C}_{14} \mathrm{H}_{28} \mathrm{O}_{2}$, which would accommodate one site of unsaturation. The distorted peak

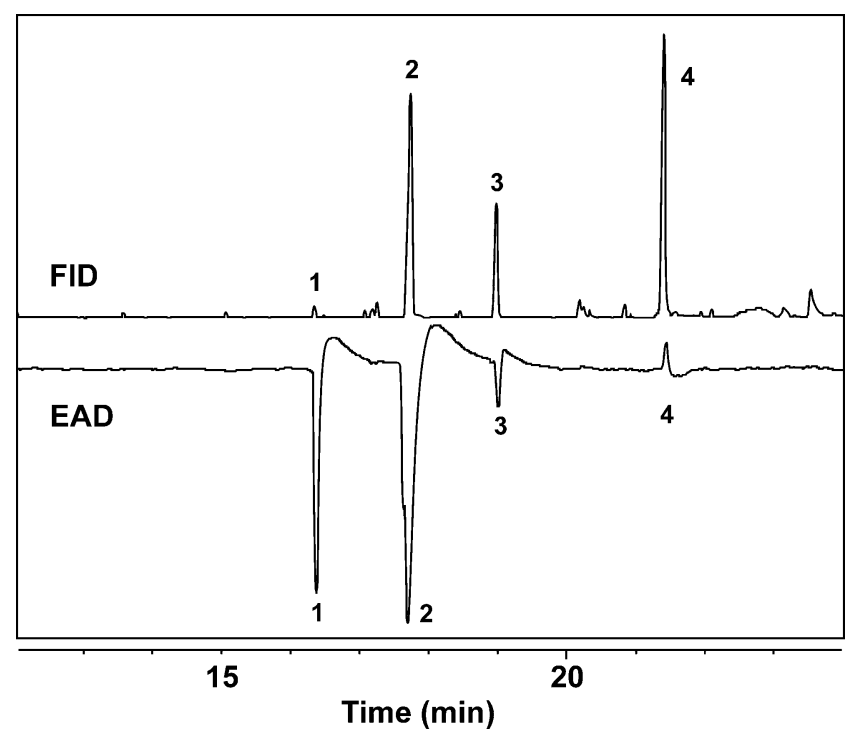

Fig. 1 Representative coupled gas chromatography-electroantennogram analysis of a contact SPME extract of the ovipositor of a female $P$. californicus. Upper trace is the chromatogram from a DB-5 GC column, lower, inverted trace is the antennal response. Peak $1=$ methyl 3,5-dimethyldodecanoate; peak $2=3,5$-dimethyldodecanoic acid; peak $3=3,5$-dimethyltridecanoic acid; peak $4=3,5$-dimethylpentadecanoic acid 
Fig. 2 Electron impact ionization mass spectra of: $\mathbf{A}$ ) the compound from the SPME extract of female ovipositor that elicited the largest antennal response from males (Peak 2 in Fig. 1, 3,5-dimethyldodecanoic acid), B) a stereoisomer of 3,5,9trimethylundecanoic acid, and C) the synthetic diastereomer of 3,5-dimethyldodecanoic acid with the same retention time as the insect-produced compound
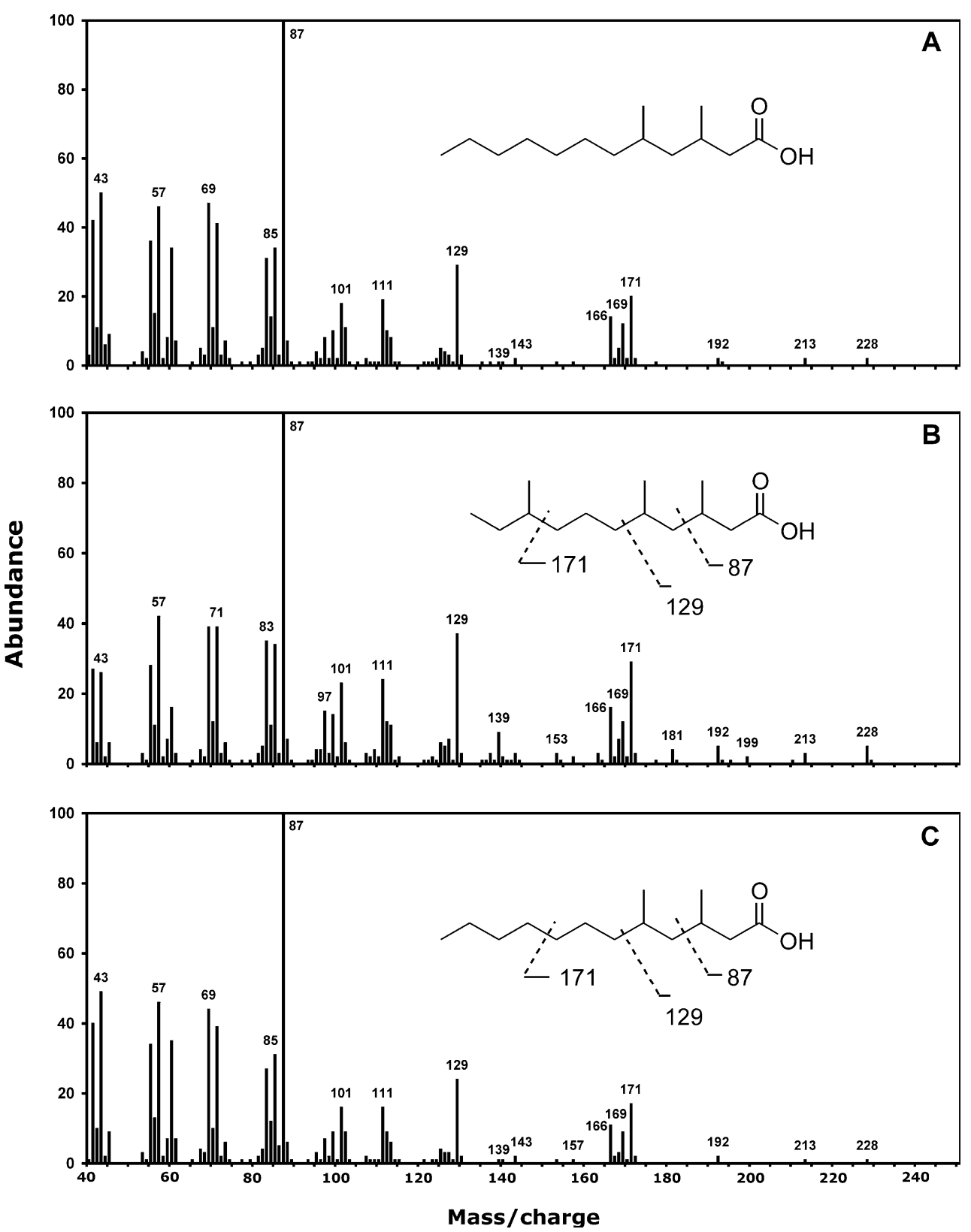

shape suggested a polar analyte such as a diol or carboxylic acid. Further evidence of a polar analyte was obtained by comparison of the Kovats indices (KI; Van den Dool and Kratz 1963; Kovats 1965) of the compound on a nonpolar DB-5 column (1636) vs. the KI value on a polar DB-WAX column (2541). The large difference between the two columns (905 KI units) was virtually identical to the corresponding difference in KI values for a model compound, tridecanoic acid, on DB-5 (1677) and DB-WAX (2585, difference $908 \mathrm{KI}$ units). The carboxyl function accounted for the single site of unsaturation, indicating that the compound could have no other double bonds or rings. Furthermore, the fact that the KI values of the insectproduced compound were actually lower than those of tridecanoic acid, even though tridecanoic acid contained one less carbon, indicated that the compound was a branched rather than a straight-chain structure.

Detailed examination of the mass spectrum (Fig. 2A) provided further information. The base peak at $\mathrm{m} / \mathrm{z} 87$ was tentatively assigned to a carboxylic acid with a methyl branch at the carbon $B$ to the carboxyl function $\left(C_{3}\right)$. A second significant fragment at $\mathrm{m} / \mathrm{z} 129$ suggested a second methyl branch at $\mathrm{C}_{5}$. The ion at $\mathrm{m} / z 171$ suggested a third methyl branch at either $\mathrm{C}_{7}$ or at $\mathrm{C}_{9}$ if cleavage had occurred closer to the end of the chain. Other useful fragments included a relatively strong $\mathrm{m} / \mathrm{z} 60$ ion, from loss of acetic acid, and even-mass ions at $m / z 192\left(\right.$ loss of $2 \times \mathrm{H}_{2} \mathrm{O}$ ) and 166 (loss of $\mathrm{C}_{2} \mathrm{H}_{6} \mathrm{O}_{2}$ ). 
The additional component that elicited the first antennal response (Fig. 1, peak 1) was tentatively identified as the methyl ester of the major pheromone component and provided further support for some of the structural elements of the parent compound. Its mass spectrum was characterized by a base peak at $m / z 74$ from McLafferty rearrangement of a methyl ester with two hydrogen on the carbon $\alpha$ to the carbonyl group, a large fragment at $m / z 101$ (65\%) from cleavage of a methyl ester with a methyl branch on $\mathrm{C}_{3}$, a weak molecular ion at $\mathrm{m} / \mathrm{z} 242(2 \%)$, and two significant fragments at $m / z 143(10 \%)$ and $185(9 \%)$, analogous to the fragments at $m / z 129$ and 171 in the spectrum of the parent acid, after accounting for the additional 14 mass units from the methyl ester.

Based on the above data, the 3,5,9-trimethylundecanoic acid structure was deemed the most likely structure, and this compound was synthesized as a mixture of all eight stereoisomers, which appeared as three broad, overlapping peaks on GC analysis. The mass spectra of the synthetic 3,5,9-trimethylundecanoic acid isomers were similar but not quite identical to that of the insect-produced compound (Fig. 2B). One of the key discriminating factors was the difference in the ratio of the low intensity ions at $\mathrm{m} / \mathrm{z} 139$ and 143 between the spectra of all of the 3,5,9-trimethylundecanoic acids and the natural compound. Because of the uncertainty in measuring the Kovats indices of these broad and overlapping peaks, which also were concentration-dependent, the mixture of acids was methylated, and the KI values of the methyl esters were compared to that of the trace amount of the methyl ester of the pheromone that was present in the insect extract (Fig. 1, peak 1). The mixture of methyl ester diastereomers appeared as two peaks on the DB-5 column, and the KI values of both were significantly shorter (1558 and 1567) than that of the insect-produced compound (1600), proving that the 3,5,9trimethylundecanoic acid structure was not correct. Furthermore, the synthetic material was virtually inactive in both laboratory and field bioassays (JDB, unpublished data).

We reasoned that another trimethyl branched alternative, i.e., 3,5,7-trimethylundecanoic acid, was even less likely to be correct because shifting the outermost methyl group inwards towards the middle of a hydrocarbon chain would further decrease the retention time. This was verified by synthesis of standards; the KI values of the four diastereomeric methyl esters $(1518,1526,1538,1547)$ were all considerably lower than that of the insect produced compound, and the mass spectra were all obviously different than that of the natural product.

A third trimethyl-branched alternative, 3,5,9-trimethylundecanoic acid, also was ruled out by synthesis of standards; the mass spectrum of the natural compound and those of the synthetic isomers were markedly different, and the Kovats indices on DB-5 $(1569,1574,1608)$ of the three peaks from the methyl esters of the mixture of synthetic stereoisomers did not match that of the insectproduced compound.

Having eliminated what seemed to be the most reasonable structures based on the mass spectral data, and with the information that the Kovats indices suggested a longer chain with fewer branch points, we then considered which dimethyldodecanoic acids might fit the data. Of the significant mass spectral fragments, the assignment of the $m / z 87$ base peak as a fragment arising from cleavage of a carboxylic acid with a methyl branch at $\mathrm{C}_{3}$ seemed robust, based on examination of database spectra of saturated carboxylic acids with a methyl group in the three position. Thus, the most likely positions for the remaining methyl group were at either $\mathrm{C}_{5}$ (supporting the fragment at $\mathrm{m} / \mathrm{z}$ 129) or $\mathrm{C}_{8}$ (supporting the fragment at $\mathrm{m} / \mathrm{z} 171$ ), with biosynthetic considerations favoring the former. Nonstereoselective synthesis of 3,5-dimethyldodecanoic acid resulted in a mixture in which the syn and anti-diastereomers were separable by GC, with the later eluting peak matching the natural compound in both Kovats index and mass spectrum (Fig. 2A vs C). Further confirmation of the identification was obtained from the excellent match between the mass spectrum and Kovats index of the corresponding methyl ester with those of the insect-produced methyl ester (Fig. 1, peak 1). In total, these data confirmed that the pheromone was one of the stereoisomers of 3,5-dimethyldodecanoic acid and that the ion at $m / z 171$, despite its prominence, was not indicative of a branch point.

In addition to 3,5-dimethyldodecanoic acid and its methyl ester (Fig. 1, peaks 2 and 1, respectively), the insect extracts also contained two compounds tentatively identified as the homologs, 3,5-dimethyltridecanoic and 3,5-dimethylpentadecanoic acid (Fig. 1, peaks 3 and 4, respectively) based on the facts that their Kovats indices were approximately 100 and 300 units greater than that of the major pheromone component, and the analogies between their mass spectra and the mass spectra of 3,5dimethyldodecanoic acid. In particular, their mass spectra were similar to that of 3,5-dimethyldodecanoic acid in the lower mass ranges, being characterized by base peaks at $\mathrm{m} / \mathrm{z}$ 87 and significant ions at $m / z \quad 129$, indicative of methyl branches on $\mathrm{C}_{3}$ and $\mathrm{C}_{5}$, and a significant $\mathrm{m} / z 60$ ion from loss of acetic acid. However, their molecular ions were integer multiples of 14 mass units higher than that of 3,5dimethyldodecanoic acid, and the cluster of ions at $\mathrm{m} / \mathrm{z} 166$, 169 , and 171 corresponding to losses of 62, 59, and $57 \mathrm{Da}$ from the molecular ion of 3,5-dimethyldodecanoic acid at $\mathrm{m} / \mathrm{z}$ 228 , was replaced with analogous clusters of ions at $\mathrm{m} / \mathrm{z} 180$, 183, and $185 \mathrm{Da}$, and 208, 211, and $213 \mathrm{Da}$, respectively. A trace amount of the corresponding 3,5-dimethyltetradecanoic acid was also tentatively identified from its base peak at $m / z$ 87 , a large $m / z 129$ ion, and a cluster of ions at $m / z 194,197$, and 199. These identifications have not yet been confirmed 
Scheme 2 Synthesis of 3,5,7trimethylundecanoic acid. $a$ $\mathrm{MesCl}, \mathrm{Et}_{3} \mathrm{~N}$, ether; $\mathrm{NaI}$, acetone; $b$ CuI, iodide 10, THF; $c \mathrm{KOH}, \mathrm{MeOH} / \mathrm{H}_{2} \mathrm{O}$
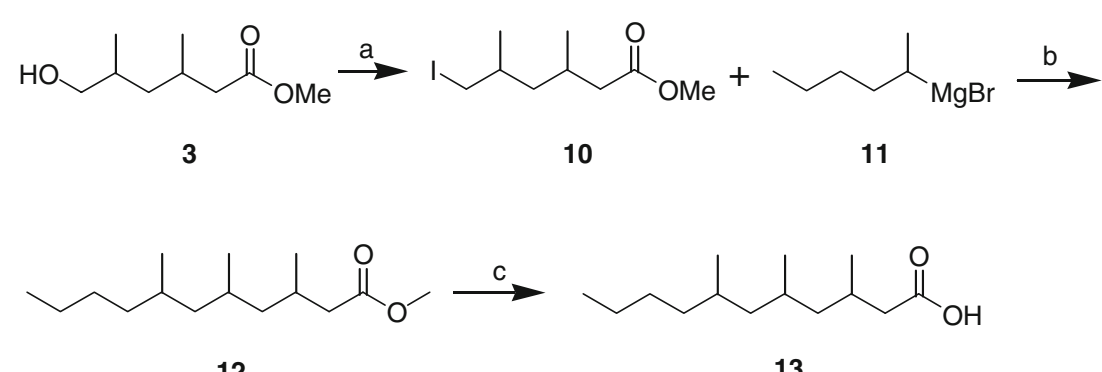

12

Field Bioassay Synthetic 3,5-dimethyldodecanoic acid as the mixture of all four stereoisomers attracted male $P$. californicus in a field bioassay. An average ( \pm SE) of $3.5 \pm$ 0.34 male beetles per trap per day were captured in traps baited with the synthetic pheromones (total over 5 days, 72 beetles), whereas no beetles were captured in control traps (means significantly different; Friedman's $Q_{1,39}=27.6$, $P<0.001)$. No females were captured. In the markrecapture portion of the assay, we recaptured only eight males that had been marked with paint and released, and Lincoln-Peterson estimates of local population size averaged ( \pm SD) $280 \pm 230$ male $P$. californicus.

\section{Discussion}

Whole body extracts of female $P$. californicus have been shown to be highly attractive to males (Barbour et al. 2006), but they contain a plethora of cuticular hydrocarbons and other contaminants that obscure possible pheromone components. Similarly, attempts to collect sufficient pheromone for analysis by using dynamic headspace collection, trapping odors released by unmated female beetles on activated charcoal, were unsuccessful; after elution with both polar and nonpolar solvents, the resulting extracts were minimally attractive to male beetles. Analyses of the compounds absorbed from the inside of the ovipositor, however, showed that the main pheromone component had been collected in detectable amounts by this method, along with several homologs.

The identification of the pheromone was confounded by the small amounts of pheromone that could be recovered in insect extracts, and by the fact that the contact SPME method of extracting and analyzing the pheromone provided in a single step.

Scheme 3 Synthesis of 3,5dimethyldodecanoic acid. $a$ $\mathrm{MesCl}, \mathrm{Et}_{3} \mathrm{~N}, \mathrm{CH}_{2} \mathrm{Cl}_{2}$; $\mathrm{LiBr}$, acetone; $b \mathrm{Mg}$ turnings, THF; c CuI, ß-butyrolactone 17
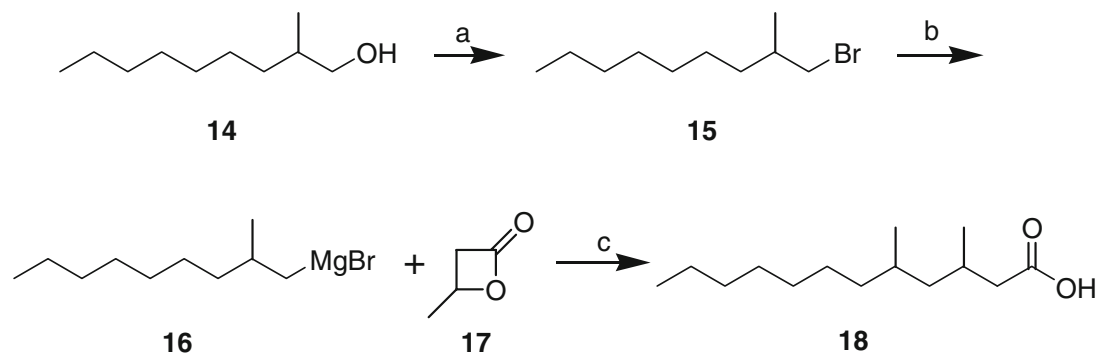
only mass spectral and retention time data. The combination of both types of data proved crucial in finally identifying the correct structure. The remarkable similarity between the mass spectra of the synthetic 3,5,9-trimethylundecanoic acid and the pheromone at first led us to believe that this structure was correct, but retention time comparisons on both the polar and nonpolar columns, with both the free acids and the corresponding methyl esters, proved that this was not possible. Detailed examination of the mass spectra showed that there were indeed small but reproducible differences between the spectra. Nevertheless, the presence of the misleading $\mathrm{m} / \mathrm{z} 171$ ion, and the corresponding ions in the homologs, is noteworthy. In fact, it had been previously noted that even straight-chain carboxylic acids display periodic enlarged fragment ions in the middle of the aliphatic chain, with no obvious source of stabilization to account for the fragmentation (McLafferty and Turecek 1993, p. 218).

Only male beetles were caught in traps baited with the synthetic 3,5-dimethyldodecanoic acid, thus verifying that this compound is a sex pheromone. The substantial number of beetles captured also suggests two other points. First, the fact that the beetles were attracted to the mixture of all four stereoisomers of 3,5-dimethyldodecanoic acid suggests that none of the "unnatural" stereoisomers are likely to be strongly antagonistic. The lack of antagonism will be a tremendous benefit for the commercialization of the pheromone for monitoring and/or control of the beetle, because as described above, 3,5-dimethyldodecanoic acid can be readily prepared in multigram quantities in a single step from two simple precursors. The relatively strong attraction obtained with 3,5dimethyldodecanoic acid also suggests that the other compounds in the extracts from females are not crucial components of the pheromone, and that racemic 3,5-dimethyldodecanoic acid as a "single" component is a satisfactory trap bait.

To our knowledge, the work described here represents the first identification of a pheromone for a species in the longhorned beetle subfamily Prioninae. However, there is considerable circumstantial evidence that female-produced sex attractant pheromones are widespread within the Prioninae (e.g., Rotrou 1936; Edwards 1961; Benham and Farrar 1976; Gwynne and Hostetler 1978), so we anticipate that pheromones of other species, particularly congeners of $P$. californicus, will soon be reported, now that the basic methods and a "lead" compound have been characterized. It should also be noted that the pheromone of P. californicus is entirely different in structure from the male-produced pheromones of species in other subfamilies of the Cerambycidae (e.g., Hanks et al. 2007; Ray et al. 2009), and femaleproduced pheromones of two species that are apparently closely related to the Cerambycidae: Migdolus fryanus Westwood and Vesperus xatarti Dufour (Leal et al. 1994; Boyer et al. 1997; taxonomy according to Napp 1994; Bense 1995; Dong and Yang 2003).
There is still considerable work to be done to complete the identification of the pheromone of P. californicus, and to use it most effectively for insect management. First, further details of the pheromone itself (e.g., which stereoisomer[s] are produced by the beetle, and the possible role of the other components in extracts) need to be worked out. Second, operational details of using the pheromone efficiently for sampling and control of this insect require optimization. Unlike some other groups of insects for which numerous pheromones are known and for which traps and pheromone release devices have been well studied, relatively little has been done with pheromone trapping of cerambycids. For example, the carboxylic acid chemistry of the $P$. californicus pheromone is unusual among insect pheromones, and release devices such as the rubber septa that are commonly used for many insect pheromones do not work well with this compound (unpub. data). Furthermore, our field observations suggest that the beetles may walk or fly towards pheromone sources, so traps should be designed to be accessible to both walking and flying insects. These and related questions will be addressed in ongoing research, so that this novel pheromone can be fully developed for management of $P$. californicus in crops where it is a chronic problem.

The online supplement to this manuscript includes the full EI mass spectra of EI mass spectrum of 3,5,7trimethylundecanoic acid, 3,5,9-trimethylundecanoic acid, 3,5-dimethyldodecanoic acid, 3,5-dimethyltridecanoic acid, 3,5-dimethylpentadecanoic acid, methyl 3,5,7-trimethylundecanoate, methyl 3,5,9-trimethylundecanoate, and methyl 3,5dimethyldodecanoate.

Acknowledgements We thank Wittko Francke for valuable discussions with regard to mass spectral interpretation, Ian Wright, Ian Swift, and David Stives for technical assistance, and Michael Long and the Los Angeles County Department of Parks and Recreation for permission to conduct research at Placerita Canyon Natural Area. This project was supported by the USDA Western Regional IPM Center, awards \#200351120-02098 and \#2007-34103-18495, and the National Research Initiative of the USDA Cooperative State Research, Education and Extension Service, grant number \#2006-35302-17457 (to JGM, JDB, LMH), and the Alphawood Foundation (to LMH).

Open Access This article is distributed under the terms of the Creative Commons Attribution Noncommercial License which permits any noncommercial use, distribution, and reproduction in any medium, provided the original author(s) and source are credited.

\section{References}

Barbour, J. D., Cervantes, D. E., Lacey, E. S., and Hanks, L. M. 2006. Calling behavior in the primitive longhorned beetle, Prionus californicus Mots. J. Insect Behav. 19:623-629.

Barbour, J. D., Lacey, E. S., Millar, J. G., and Hanks, L. M. 2007. Cuticular hydrocarbons mediate mating in the Prionine 
Cerambycid Prionus californicus Mots. Ann. Entomol. Soc. Am. 100:333-338.

BENHAM, G. S. Jr., and FARRAR, R. J. 1976. Notes on the biology of Prionus laticollis (Coleoptera: Cerambycidae). Can. Entomol. 108:569-576.

BENSE, U. 1995. Longhorned beetles, illustrated key to the cerambycidae and vesperidae of Europe. Margraf Verlag, Weikersheim, DEU.

Bishop, G. W., BlaCKMER, J. L., and BAIRD, C. R. 1984. Observations on the biology of Prionus californicus Mots. on hops, Humulus lupulus L., in Idaho. J. Entomol. Soc. British Columbia 81:20-24.

Boyer, F. D., Malosse, C., Zagatti, P., and Einhorn, J. 1997. Identification and synthesis of vesperal, the female sex pheromone of the longhorn beetle, Vesperus xatarti. Bull. Soc. Chim. France 134:757-764.

Cervantes, D. E., Hanks, L. M., Lacey, E. S., and Barbour, J. D. 2006. First documentation of a volatile sex pheromone in a longhorned beetle (Coleoptera: Cerambycidae) of the primitive subfamily Prioninae. Ann. Entomol. Soc. Am. 99:718-722.

DONG, K. Z., and YANG, X. K. 2003. Progress in classification of higher taxa of the Cerambycidae. Entomological Knowledge 40:211-217. (in Chinese).

EDWARDS, J. S. 1961. Observations on the ecology and behavior of the huhu beetle, Prionus reticularis White (Col. Ceramb). Trans. R. Soc. N.Z. 88:733-741.

Gwynne, D. T., and Hostetler, B. B. 1978. Mass emergence of Prionus emarginatus (Say) (Coleoptera: Cerambycidae). Coleop. Bull. 32:347-348.

Hanks, L. M., Millar, J. G., Moreira, J. A., Barbour, J. D., LACEy, E. S., MCElfresh, J. S., REUTER, F. R., and RAY, A. M. 2007. Using generic pheromone lures to expedite identification of aggregation pheromones for the cerambycid beetles Xylotrechus nauticus, Phymatodes lecontei, and Neoclytus modestus modestus. J. Chem. Ecol. 33:889-907.

KOVATS, E. 1965. Gas chromatographic characterization of organic substances in the retention index system. Adv. Chromatogr. $1: 229-247$.
LAWrence, J. F. 1982. Coleoptera, pp. 482-553, in S. P. Parker (ed.) Synopsis and Classification of Living Organisms, Vol. 2. McGraw-Hill, New York.

LEAL, W. S., BENTO, J.M.S., VIlela, E. F., and Della LuCia, T. M. C. 1994. Female sex pheromone of the longhorn beetle Migdolus fryanus Westwood: N-(2'S)-methylbutanoyl 2-methylbutylamine. Experientia 50:853-856.

Linsley, E. G. 1962. The cerambycidae of North America. Part II. Taxonomy and classification of the Parandrinae, Prioninae, Spondylinae, and Aseminae. Univ. Calif. Publ. Entomol. 19:1-102.

MCLAFFERTY, F. W., and TURECEK, F. 1993. Interpretation of Mass Spectra, 5th ed. University Science Books, Sausalito CA. 371 pp.

NAPP. D. S. 1994. Phylogenetic relationships among the subfamilies of Cerambycidae (Coleoptera - Chrysomeloidea). Rev. Bras. Entomol. 38:265-419.

Ray, A. M., Millar, J. G., McElfresh, J. S., SWift, I. P., Barbour, J. D., and HANKS, L. M. 2009. Male-produced aggregation pheromone of the cerambycid beetle Rosalia funebris. J. Chem. Ecol. 35:96-103.

Rotrou, P. 1936. Le Cyrtognathus forficatus F. ses Moeurs. Bull. Soc Sci. Nat. Maroc. 16:246-251.

SAS INSTITUTE. 2001. SAS/STAT User's Guide for Personal Computers, Release 8.01. SAS Institute, Cary, NC.

Sato, T., Kawara, T., Kawashima, M., and Fujisawa, T. 1980. Copper-catalyzed reaction of Grignard reagents with ß-propiolactones: a convenient method for the synthesis of $\beta$-substituted propionic acids. Chem. Lett. 1980:571-574.

SOKAL, R. R., and RoHLF, F. J. 1995. Biometry, 3rd ed. W. H. Freeman, New York, NY.

SolomON, J. D. 1984. Guide to Insect Borers in North American Broadleaf Trees and Shrubs. USDA Forest Service Agriculture Handbook AH-706. USDA, Washington DC

Southwood, T. R. E., and HeNDERSON, P. A. 2000. Ecological Methods, 3rd ed. Blackwell Science, Oxford, UK

VAN DEN Dool, H., and KRATZ, P. D. 1963. A generalization of the retention index system including linear temperature programmed gas-liquid partition chromatography. J. Chromatog. A. 11:463-471. 